\title{
Synthesis of Nickel-loaded Sulfated Zirconia Catalyst and Its Application for Converting Used Palm Cooking Oil to Gasoline via Hydrocracking Process
}

\author{
Ilyas Taufik Abdul Aziz¹, Wahyu Dita Saputri², Wega Trisunaryanti³ ${ }^{3}$ Sri Sudiono3, \\ Akhmad Syoufian ${ }^{3}$, Arief Budiman4, Karna Wijaya ${ }^{3 *}$ \\ 1 Department of Analytical Chemistry, Politeknik AKA Bogor, Jl. Pangeran Sogiri No. 283, Tanah Baru, 16154 Bogor, Indonesia \\ ${ }^{2}$ Research Center for Physics, National Research and Innovation Agency (BRIN), Puspiptek, Building 440-442, Muncul, Setu, \\ South Tangerang City, 15314 Bantan, Indonesia \\ ${ }^{3}$ Department of Chemistry, Faculty of Mathematics and Natural Sciences, Universitas Gadjah Mada, Sekip Utara, P. O. B. BLS 21, \\ Depok, 55281 Yogyakarta, Indonesia \\ ${ }^{4}$ Department of Chemical Engineering, Faculty of Engineering, Universitas Gadjah Mada, Jl. Grafika No. 2, 55281 Yogyakarta, \\ Indonesia \\ * Corresponding author, e-mail: karnawijaya@ugm.ac.id
}

Received: 17 March 2021, Accepted: 11 June 2021, Published online: 06 October 2021

\begin{abstract}
The synthesis of the nickel-loaded sulfated zirconia catalyst (Ni-SZ) and its application for the hydrocracking process have been carried out. This work has been conducted to determine the activity and selectivity from various Ni concentrations loaded on sulfated zirconia (SZ) in the hydrocracking of used palm cooking oil. The synthesis technique was preceded by sulfation of $\mathrm{ZrO}_{2}$ through incipient wetness impregnation method using $\mathrm{H}_{2} \mathrm{SO}_{4}$ solution and then continued with the impregnation of Ni via hydrothermal method employing $\mathrm{NiSO}_{4} \cdot 6 \mathrm{H}_{2} \mathrm{O}$ precursor salt. The hydrocracking process was performed in a fix-bed microreactor at the optimum temperature $\left(350^{\circ} \mathrm{C}\right)$. The SZ loaded with $3 \mathrm{wt} \%$ of $\mathrm{Ni}(\mathrm{Ni}-\mathrm{SZ} 3$ ) successfully produced the highest liquid product (44.25 wt\%) and selectivity on gasoline (100\%). Besides, the gasoline fraction in the liquid product was dominated by unwanted aromatics compounds. The excellent performance of Ni-SZ 3 due to it has high acidity value, specific surface area, and Ni content.
\end{abstract}

\section{Keywords}

catalyst, sulfated zirconia, nickel, hydrothermal, hydrocracking

\section{Introduction}

Cooking oil is commonly used in food processing, and its production increase along with the population and food processing facilities [1]. A large amount of used cooking oil triggers complex problems when not handled carefully [2]. There are several methods to process used cooking oil into biofuels, such as thermal, hydro, and catalytic cracking. Hydrocracking has more moderate operating conditions than thermal cracking and a longer catalyst lifetime than catalytic cracking, so this method is more economically feasible [3]. Hydrocracking is a combination of catalytic cracking and hydrogenation that converts large to smaller compounds [4]. The effectivity of the hydrocracking process is affected by the types and characteristics of the catalysts used [5-7].

Nanoparticle materials are an excellent candidate for catalyst purposes due to their large surface area and highly active catalytic properties [8]. Nanozirconia $\left(\mathrm{ZrO}_{2}\right)$ is an oxide-based nanoparticle material that has the potential to be employed as a hydrocracking catalyst due to its acidic sites, high thermal stability, high melting point, high chemical stability, high ionic conductivity, and low thermal conductivity $[9,10]$. The stability and catalytic performance of $\mathrm{ZrO}_{2}$ can be increased by coating its surface with sulfate to produce SZ [11]. Furthermore, the addition of sulfate increase the number of Brønsted and Lewis acid sites in the $\mathrm{ZrO}_{2}$ structure $[12,13]$. The stability, acidity, and catalytic performance of SZ depend on some factors, such as preparation method, surface area, source of zirconia, source of sulfate, processing $\mathrm{pH}$ value, temperature, aging time, calcination temperature, and environment of storage [14-16].

Several studies have shown that SZ has high catalytic activity only at the beginning of the reaction, and it can be overcome by a modification technique using noble 
metals [17]. The application of noble metals that are relatively expensive can reduce economic feasibility, so applying other alternative metals is considered necessary. Nickel is a metal potentially to replace the role of noble metals due to its high hydrogenation activity, and in terms of cost, it is cheaper [18]. Several studies show that modifications of catalysts with Ni could increase the hydrogenation reactivity, the acidity value, and the number of hydrocracking products $[19,20]$. Several studies also proved that modification catalyst using $\mathrm{Ni}$ is potentially applied in the hydrocracking of isopropyl benzene, crude oil coal, and petroleum sludge waste [21]. The Ni-SZ catalyst is very potential to be used in the conversion of used palm cooking oil into biogasoline through hydrocracking. Because in this catalyst, there is SZ which provides acidity (plays a role in the cracking process) and $\mathrm{Ni}$ which has hydrogenation activity (for the hydrogenation process). The conversion of used palm cooking oil to biogaoline can occur through several reaction stages, starting from the saturation of unsaturated triglycerides, followed by the decomposition of triglycerides into fatty acids. Furthermore, there are hydrodeoxygenation, decarboxylation and hydrodecarbonylation processes to produce hydrocarbons. The existing hydrocarbons then undergo cracking to produce biogasoline and other fractions [22]. Although its potential for hydrocracking of use palm cooking oil is there, however it has not yet been reported.

This work presents the synthesis of Ni-SZ with various Ni concentrations loaded on sulfated zirconia (SZ) for hydrocracking of used palm cooking oil to produce gasoline. This study aims to determine the nickel concentration that produces the highest activity and selectivity on the hydrocracking of used palm oil.

\section{Materials and methods \\ 2.1 Materials}

Zirconia powder $\left(\mathrm{ZrO}_{2}\right)$ was supplied from Jiaozou Huasu Chemical Co., Ltd (particle size 60-70 nm, purity $99 \%$ ).

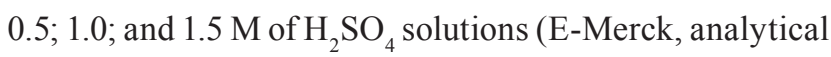
grade), $\mathrm{NH}_{3}$ solution $25 \mathrm{wt} \%$ (E-Merck, analytical grade), $\mathrm{NiSO}_{4} \cdot 6 \mathrm{H}_{2} \mathrm{O}$ (purity $\geq 99 \%$, E-Merck, analytical grade), $\mathrm{H}_{2}$ gas (purity $\geq 99 \%$ ) from PT. Samator, distilled water, and used palm cooking oil from a fried chicken restaurant in Yogyakarta with high availability and low price.

\subsection{Methods}

\subsubsection{Synthesis of $\mathrm{SZ}$}

SZ was synthesized using an incipient wetness impregnation method. $10 \mathrm{~g}$ of $\mathrm{ZrO}_{2}$ was stirred with $50 \mathrm{~mL}$ of $0.5,1.0$, and $1.5 \mathrm{M} \mathrm{H}_{2} \mathrm{SO}_{4}$ solutions for $24 \mathrm{~h}$ at room temperature. The obtained colloidal suspension was centrifuged at $1800 \mathrm{rpm}$ for $15 \mathrm{~min}$. The solids that resulted from centrifugation were dried at $110{ }^{\circ} \mathrm{C}$ for $24 \mathrm{~h}$. The resulting materials were labeled as SZ 0.5, SZ 1.0, and SZ 1.5, respectively. SZ X with the highest acidity value (SZ 1.5) was calcined at 500, 550, 600, 650, and $700{ }^{\circ} \mathrm{C}$ for $5 \mathrm{~h}$. After that, the catalyst was crushed and sieved at 150 mesh. The products were labeled SZ X-500; 550; 600; $650 ; 700$, respectively.

\subsubsection{The synthesis of Ni-SZ}

Synthesis of nickel-loaded sulfated zirconia (Ni-SZ) was carried out by the hydrothermal method. $5 \mathrm{~g}$ of calcined SZ X with the highest acidity value (SZ 1.5-500) was mixed with $50 \mathrm{~mL} \mathrm{NiSO} \cdot 6 \mathrm{H}_{2} \mathrm{O}$ aqueous solution that corresponded to $1,2,3 \mathrm{wt} \% \mathrm{Ni}$ in stainless steel autoclave without magnetic stirrer then heated in the oven at $110^{\circ} \mathrm{C}$ for $5 \mathrm{~h}$. The solids obtained were dried at $100{ }^{\circ} \mathrm{C}$ for $24 \mathrm{~h}$ and then calcined at $500{ }^{\circ} \mathrm{C}$ for $4 \mathrm{~h}$ (rate of heating and cooling is $25^{\circ} \mathrm{C} / \mathrm{min}$ ). The next step was the reduction of $4 \mathrm{~g}$ catalyst sample in the reduction reactor under $\mathrm{H}_{2}$ gas flow rate $20 \mathrm{~mL} / \mathrm{min}$, and the reactor was set up at $400{ }^{\circ} \mathrm{C}$ for $4 \mathrm{~h}$. Then, the catalyst was crushed and sieved at 150 mesh. The obtained catalysts were labeled Ni-SZ 1, Ni-SZ 2, and Ni-SZ 3, respectively.

\subsubsection{Characterization methods}

The identification of the functional groups in the catalysts was carried out using a Fourier Transform Infrared spectrometer (FTIR, Shimadzu FTIR 8201 PC) equipped with the data station in the range of $400-4000 \mathrm{~cm}^{-1}$ with a $\mathrm{KBr}$ disc technique. The acidity of the catalysts was determined by the gravimetric method based on $\mathrm{NH}_{3}$ gas adsorption and followed by FTIR analysis. The crystallinity and crystal size were characterized by X-Ray Diffractometer (XRD, Shimadzu Model XRD 6000, $\lambda=1.54 \AA$, $40 \mathrm{kV}$, $30 \mathrm{~mA}$ ) with the source of $\mathrm{Cu} K \alpha$ radiation (Ni filtered), patterns were recorded from $4-80^{\circ}(2 \theta)$, step size $0.017^{\circ}$ $2 \theta$, scan step time 10.1500 s. Crystal size was estimated by Scherrer equation: $D=(K \lambda) /(\beta \cos \theta)$; where $D$ is the average of crystallite size (nm), $K$ is Scherrer constant (0.89), $\lambda$ is the X-ray wavelength, $\beta$ is the observed angular width at half maximum intensity of the peak and $\theta$ is Bragg's angle. Surface morphology, composition, and elements distribution in the catalysts were characterized by Scanning Electron Microscope-Energy Dispersive Spectrometer mapping (SEM-EDS Mapping, JEOL JED 2300 Analysis Station, $15 \mathrm{kV}$ ). The concentration of Ni within Ni-SZ was analyzed by an Inductively Coupled Plasma spectrometer 
(ICP, ICPE-9820). Sample preparation for analysis of ICP was done with $0.5 \mathrm{~g}$ sample was added with $15 \mathrm{~mL}$ of aquaregia. The suspension was then stirred on the heating plate for $3 \mathrm{~h}$. The resulting solution was diluted to $100 \mathrm{~mL}$, and the concentration of Ni determine by calibration curve $(r=0.99964)$. Meanwhile, the specific surface area, total pore volume, average pore diameter, and pore distribution were analyzed by Gas Sorption Analyzer (GSA, Quadra Sorb Station 2 7.01). For each GSA analysis, $0.3 \mathrm{~g}$ of sample was used. The sample was thoroughly outgassed for $2 \mathrm{~h}$, at $300^{\circ} \mathrm{C}$, bath temperature of $-195.85^{\circ} \mathrm{C}$, and equilibration time of 120 /variable sec (ads/des), then the weight of the outgassed sample was used in calculations.

\subsubsection{Total acidity test of catalyst}

The acidity test was performed by heating the empty porcelain cup at $150{ }^{\circ} \mathrm{C}$ for $2 \mathrm{~h}$ then weighed; the mass was noted as $W_{0}$. A total of $0.1 \mathrm{~g}$ of sample was put into the porcelain cup, then heated at $150{ }^{\circ} \mathrm{C}$ for $2 \mathrm{~h}$ and weighed. The mass of porcelain cup + sample was noted as $W_{1}$. The porcelain cup with a sample was put into a desiccator that contains $\mathrm{NH}_{3}$ gas and allowed for $24 \mathrm{~h}$. The porcelain cup+sample that has adsorbed the $\mathrm{NH}_{3}$ gas was then weighed and noted as $W_{2}$. The calculation of total acidity of the catalyst was calculated with Eq. (1).

Total acidity $\left(\mathrm{mmol} \mathrm{g}^{-1}\right)=\frac{W_{2}-W_{1}}{\left(W_{1}-W_{0}\right) \times M r \mathrm{NH}_{3}}$

\subsubsection{Hydrocracking process}

The hydrocracking process was performed in a fix-bed microreactor system. Scheme of the reactor was depicted in Fig. 1 [23].

Before the hydrocracking process was carried out, the determination of optimum temperature must be performed by thermal cracking of used cooking oil at 325, 350, and $375^{\circ} \mathrm{C}$ (heating and cooling rate were $20{ }^{\circ} \mathrm{C} / \mathrm{min}$ ) under $\mathrm{H}_{2}$ gas flow condition at $10 \mathrm{~mL} / \mathrm{min}$ for $1 \mathrm{~h}$. The product was

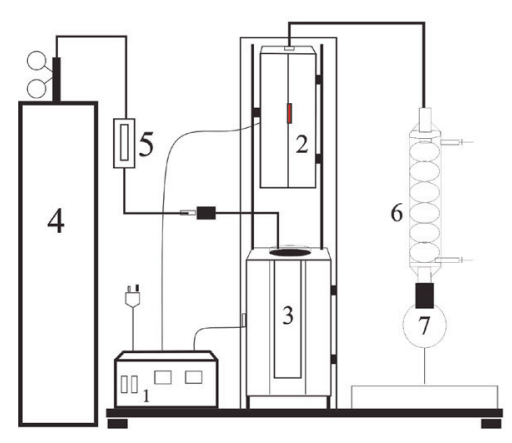

1. Thermocouple

2. Catalyst Containeı

3. Feed Container

4. $\mathrm{H}_{2}$ container

5. $\mathrm{H}_{2}$ flowmeter

6. Condenser

7. Product container

Fig. 1 Scheme of the hydrocracking reactor [23] collected in the cold trap for $1 \mathrm{~h}$. Optimum temperature was the temperature that produces the highest liquid product. The hydrocracking process of used cooking oil with catalysts $\mathrm{ZrO}_{2}$, SZ $X-Y(X=1.5, Y=500)$, Ni-SZ 1, Ni-SZ 2, and $\mathrm{Ni}-\mathrm{SZ} 3$ was carried out under $\mathrm{H}_{2}$ gas flow conditions at $10 \mathrm{~mL} / \mathrm{min}$, in optimum temperature (heating and cooling rate were $20{ }^{\circ} \mathrm{C} / \mathrm{min}$ ) and the mass ratio of catalysts and used cooking oil was 1:100 (catalyst mass was $0.1 \mathrm{~g}$ and feed mass was $10 \mathrm{~g}$ ) for $1 \mathrm{~h}$. The product collected in the cold trap for $1 \mathrm{~h}$ were weighed and characterized by gas chromatography-mass spectrometry (GC-MS Shimadzu QP 2010S), and Rtx 5 column (30 m length, $0.25 \mathrm{~mm}$ internal diameter), Helium (He) as the carrier gas, and electron ionization detector. Set up method in this analysis was the column oven temperature: $50.0{ }^{\circ} \mathrm{C}$, injection temperature: $310.00{ }^{\circ} \mathrm{C}$, injection mode: split flow control mode: pressure, pressure: $13.0 \mathrm{kPa}$, total flow: $40.0 \mathrm{~mL} / \mathrm{min}$, column flow: $0.55 \mathrm{~mL} / \mathrm{min}$, linear velocity: $26.8 \mathrm{~cm} / \mathrm{sec}$, purge flow: $3.0 \mathrm{~mL} / \mathrm{min}$, split ratio: 66 . The conversion of feed to yield was calculated with Eqs. (2)-(6):

Liquid Yield $(w t \%)=\frac{W L P}{W F} \times 100 \%$,

Residue $(w t \%)=\frac{W R}{W F} \times 100 \%$,

Coke $(w t \%)=\frac{W U C-W F C}{W F} \times 100 \%$,

Gas Product $(w t \%)=\frac{W F-(W L P+W R+W C)}{W F} \times 100 \%$,

Selectivity of liquid yields

$=\frac{\% \text { area GC-MS fraction } C x-C y}{\% \text { total area GC-MS }} \times 100 \%$.

Explanations are:

- WLP: Weight of Liquid Product

- WR: Weight of Residue

- WUC: Weight of Used Catalyst

- WFC: Weight of Fresh Catalyst

- WC: Weight of Coke

- WF: Weight of Feed.

\section{Results and discussion}

\subsection{Fourier Transform Infrared (FTIR)}

The FTIR spectra of $\mathrm{ZrO}_{2}$ that sulfated with $0.5 \mathrm{M} ; 1.0 \mathrm{M}$; $1.5 \mathrm{M} \mathrm{H}_{2} \mathrm{SO}_{4}$ are depicted in Fig. 2. All of these materials show bands at 424-471, 1627-1635, and $3400 \mathrm{~cm}^{-1}$, 


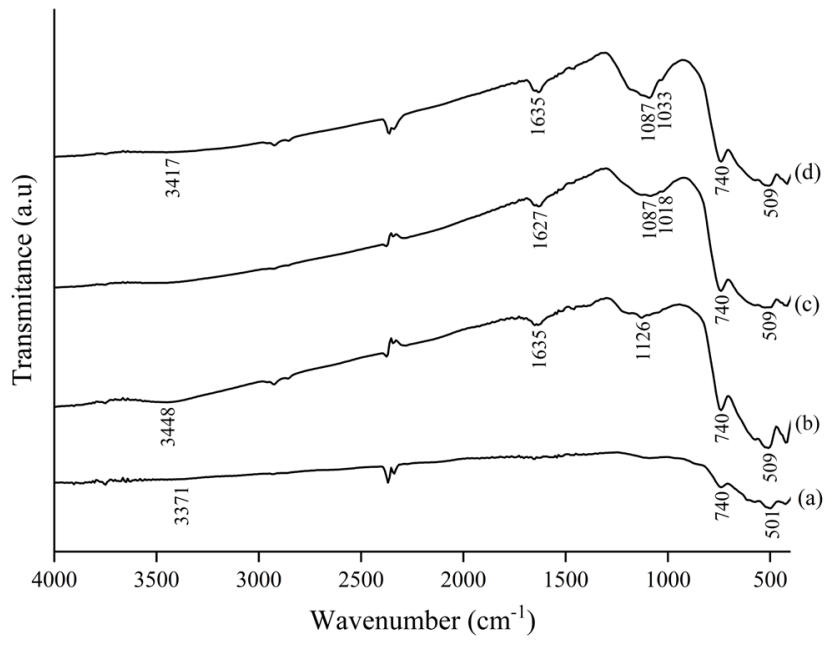

Fig. 2 FTIR spectra of (a) $\mathrm{ZrO}_{2}$; (b) SZ 0.5; (c) SZ 1.0; (d) SZ 1.5

which correspond to $\mathrm{Zr}-\mathrm{O}-\mathrm{Zr}$ stretching vibration, $\mathrm{H}-\mathrm{O}-\mathrm{H}$ bending vibration, and $\mathrm{O}-\mathrm{H}$ stretching vibration, respectively $[24,25]$. In the SZ spectra, there are bands at 1018 $1126 \mathrm{~cm}^{-1}$ that corresponded to sulfate vibration mode groups [9]. These bands indicate that sulfate has already impregnated on the $\mathrm{ZrO}_{2}$. The higher $\mathrm{H}_{2} \mathrm{SO}_{4}$ concentration that was used, the band at $1018-1126 \mathrm{~cm}^{-1}$ becomes sharper that indicates the increase of the amount of sulfate in the SZ.

The FTIR spectra of SZ 1.5 that calcinated at $500{ }^{\circ} \mathrm{C}$; $600{ }^{\circ} \mathrm{C} ; 650^{\circ} \mathrm{C} ; 700{ }^{\circ} \mathrm{C}$ are showed in Fig. 3. Based on Fig. 3, the spectra of calcined SZ 1.5 show the decreasing band intensity at $1002-1126 \mathrm{~cm}^{-1}$ (sulfate vibration mode groups) when the calcination temperature increase. These results indicate that the increasing temperature decomposes the sulfate group more intensely [26]. The sulfate that weakly bonded with surface hydroxyl group will be loss when increasing the calcination temperature [27].

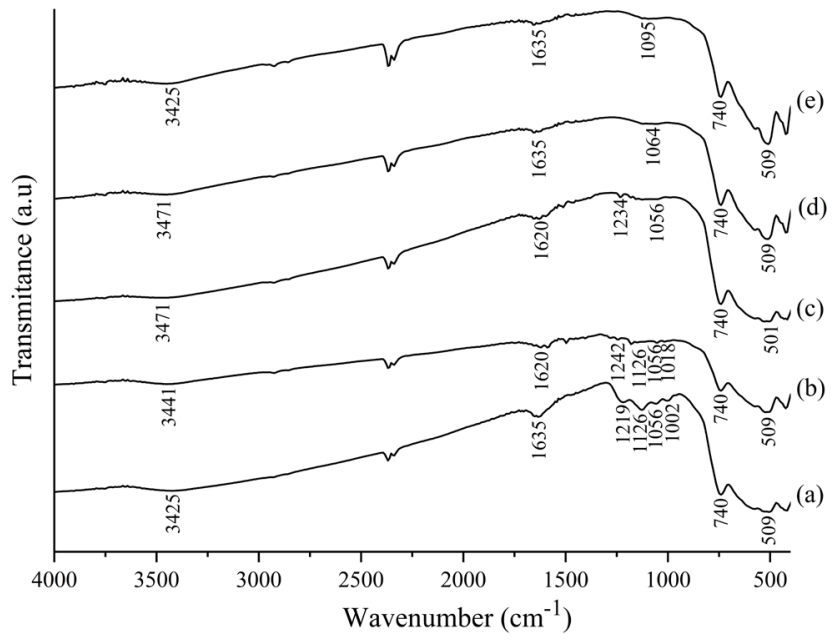

Fig. 3 FTIR spectra of (a) SZ 1.5-500; (b) SZ 1.5-550; (c) SZ 1.5-600; (d) SZ 1.5-650; (e) SZ 1.5-700
The FTIR spectra of SZ 1.5-500, SZ 1.5-500 that loaded with $1 \mathrm{wt} \%$ of $\mathrm{Ni}(\mathrm{Ni}-\mathrm{SZ} 1), 2 \mathrm{wt} \%$ of $\mathrm{Ni}(\mathrm{Ni}-\mathrm{SZ} 2)$, and $3 \mathrm{wt} \%$ of Ni (Ni-SZ 3) are depicted in Fig. 4. Spectra in Fig. 4 show that impregnation of Ni reduces the intensity at $1002,1056,1126$, and $1219 \mathrm{~cm}^{-1}$. These results reflect the decrease of the sulfate group caused by heat treatment in the reduction catalyst step. The intense band at 1103 and $1141 \mathrm{~cm}^{-1}$ appears in the Ni-SZ catalyst. These two bands indicate the presence of the solid superacid structure. The bands that appear around 1103 and $1141 \mathrm{~cm}^{-1}$ correspond to the symmetry O-S-O stretching of bidentate persulfate ion coordinated with $\mathrm{Ni}$ [28]. The intensity band at 1103 and $1141 \mathrm{~cm}^{-1}$ increase with increasing $\mathrm{Ni}$ concentration. This is indicated that the bidentate persulfate ion that coordinated with $\mathrm{Ni}$ increase.

\subsection{Acidity test}

Determination of the catalyst total acidity values is carried out by the gravimetric method based on the adsorption of ammonia $\left(\mathrm{NH}_{3}\right)$ gas, shown in Table 1 . The acidity of $\mathrm{ZrO}_{2}$ comes from $\mathrm{Zr}^{4+}$ that acts as Lewis acid [17]. Based on the data shown in Table 1, the higher $\mathrm{H}_{2} \mathrm{SO}_{4}$ concentration for $\mathrm{ZrO}_{2}$ modification increases the acidity value due to the formation of polydentate surface $\mathrm{SO}_{4}$ species, conferring significant Brønsted acidity [28, 29].

The other results show that a higher calcination temperature causes the decrease of acidity value because of the sulfate decomposition as a consequence of the decrease Brønsted and Lewis acid site in the SZ catalyst [30]. The amount of Ni that load in SZ 1.5-500 affects the acidity because $\mathrm{Ni}$ can increase the acidity of the catalyst. The partially-charged orbitals of $\mathrm{Ni}$ are effective in accepting an electron pair (Ni increase Lewis acid site) [11, 31].

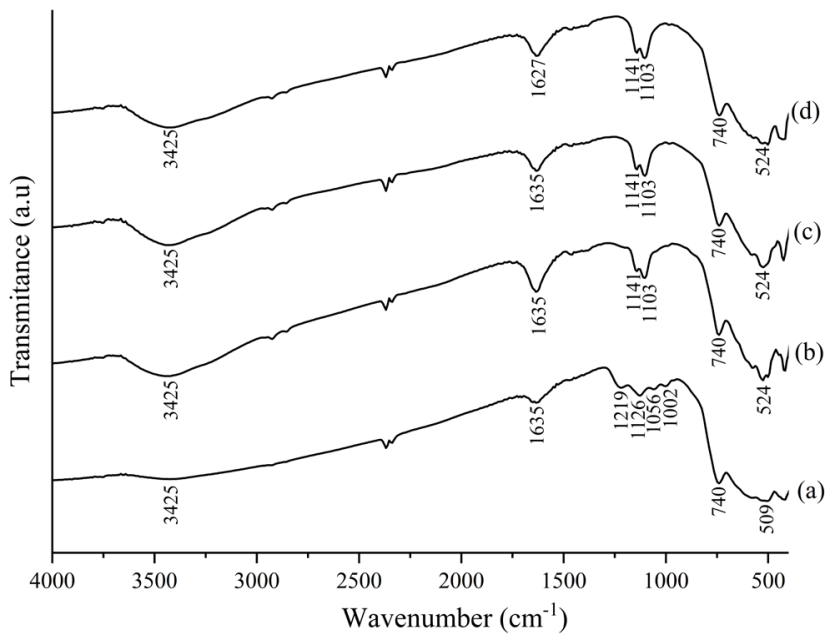

Fig. 4 FTIR spectra of (a) SZ 1.5-500; (b) Ni-SZ 1; (c) Ni-SZ 2; (d) Ni-SZ 3 
Table 1 The acidity of catalysts

\begin{tabular}{lc}
\hline Catalyst & Acidity $\left(\mathrm{mmol} \mathrm{g}^{-1}\right)$ \\
\hline $\mathrm{ZrO}_{2}$ & $0.355 \pm 0.004$ \\
$\mathrm{SZ} 0.5$ & $1.188 \pm 0.052$ \\
$\mathrm{SZ} 1.0$ & $1.304 \pm 0.009$ \\
$\mathrm{SZ} 1.5$ & $2.004 \pm 0.011$ \\
$\mathrm{SZ} 1.5-500$ & $3.639 \pm 0.029$ \\
$\mathrm{SZ} 1.5-550$ & $3.410 \pm 0.016$ \\
$\mathrm{SZ} 1.5-600$ & $2.755 \pm 0.030$ \\
$\mathrm{SZ} 1.5-650$ & $2.258 \pm 0.016$ \\
$\mathrm{SZ} 1.5-700$ & $2.024 \pm 0.053$ \\
$\mathrm{Ni}-\mathrm{SZ} 1$ & $3.905 \pm 0.025$ \\
$\mathrm{Ni}-\mathrm{SZ} 2$ & $4.061 \pm 0.085$ \\
$\mathrm{Ni}$ SZ 3 & $4.235 \pm 0.072$ \\
\hline
\end{tabular}

The acidity test results are also confirmed by FTIR characterization. Fig. 5 shows the FTIR spectra of $\mathrm{ZrO}_{2}$ and $S Z$ in different concentrations of $\mathrm{H}_{2} \mathrm{SO}_{4}$ solution used for sulfation after the acidity test These spectra show bands at 1118 and $1404 \mathrm{~cm}^{-1}$. The vibration at $1118 \mathrm{~cm}^{-1}$ indicates the presence of $\mathrm{NH}_{3}$ coordinated by Lewis acid sites, and asymmetric stretching vibration at $1404 \mathrm{~cm}^{-1}$ shows the presence of ions formed by proton transfer from the Brønsted acid site to $\mathrm{NH}_{3}$ [32]. Fig. 5 shows that the band intensities at 1118 and $1404 \mathrm{~cm}^{-1}$ become sharper when the $\mathrm{H}_{2} \mathrm{SO}_{4}$ solution concentrations get higher. These results indicate that the higher $\mathrm{H}_{2} \mathrm{SO}_{4}$ concentration is able to increase the number of Brønsted and Lewis acid sites in the catalysts.

The FTIR spectra of SZ 1.5 with various calcination temperatures after the acidity test are presented in Fig. 6. These FTIR spectra show the decreasing intensity at 1118 and $1404 \mathrm{~cm}^{-1}$ in higher calcination temperatures, indicating the decrease of Bronsted and Lewis acid sites.

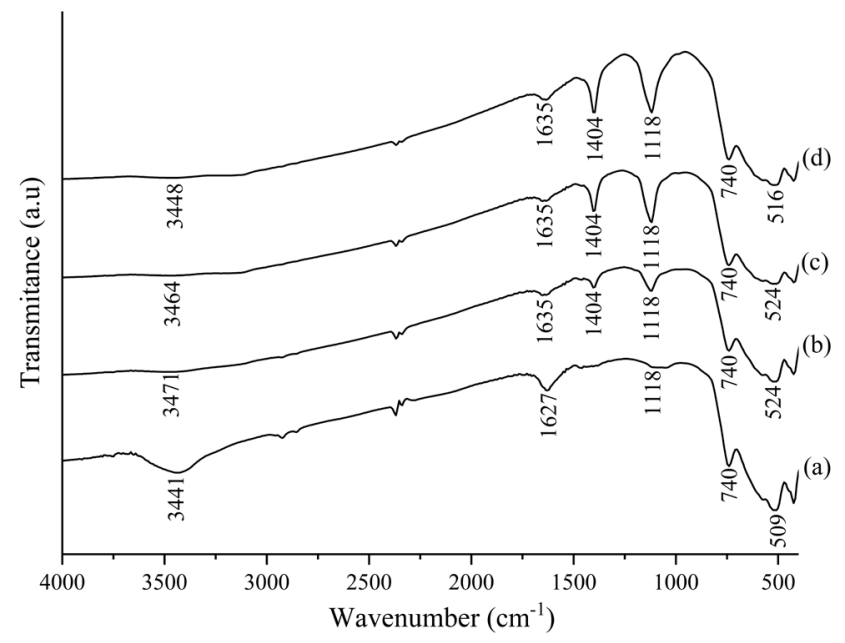

Fig. 5 FTIR spectra of (a) $\mathrm{ZrO}_{2}$; (b) SZ 0.5; (c) SZ 1.0; (d) SZ 1.5 after acid test

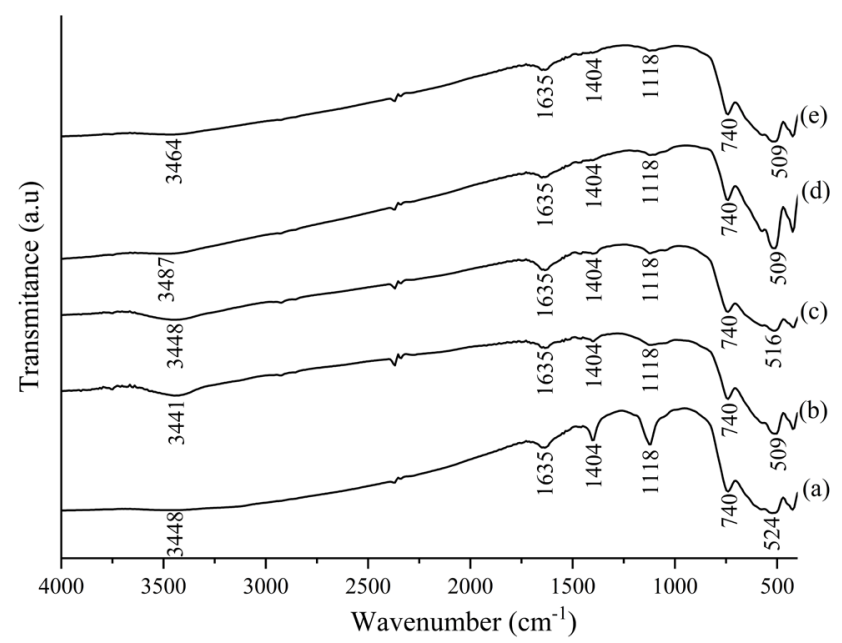

Fig. 6 FTIR spectra of (a) SZ 1.5-500; (b) SZ 1.5-550; (c) SZ 1.5-600; (d) SZ 1.5-650; (e) SZ 1.5-700 after the acid test

Fig. 7 represents the FTIR spectra of Ni-SZ 1, Ni-SZ 2, and Ni-SZ 3 after the acidity test. These spectra show that the band intensity at 1118 and $1404 \mathrm{~cm}^{-1}$ is sharper when the concentration of $\mathrm{Ni}$ gets higher, indicating there are increasing in the number of Brønsted and Lewis acid sites.

\subsection{X-Ray Diffraction (XRD)}

Diffractograms of the $\mathrm{ZrO}_{2}, \mathrm{SZ} 1.5-500$, SZ 1.5-550, SZ 1.5-600, SZ 1.5-650, and SZ 1.5-700 are depicted in Fig. 8. Diffractograms of $\mathrm{ZrO}_{2}$ and $\mathrm{SZ} 1.5$ that calcinated at various temperature show three dominant peaks at $2 \theta=28.21^{\circ}\left(d_{-111}\right), 31.56^{\circ}\left(d_{111}\right)$, and $50.22^{\circ}\left(d_{200}\right)$, indicating the presence of $\mathrm{ZrO}_{2}$ in the monoclinic phase (JCPDS 93-0944). The absence of a significant peak shift of SZ indicates that sulfation followed with calcination does not change the crystal phase of $\mathrm{ZrO}_{2}$, and SZ 1.5-500 has a lower intensity of the three dominant peaks than $\mathrm{ZrO}_{2}$.

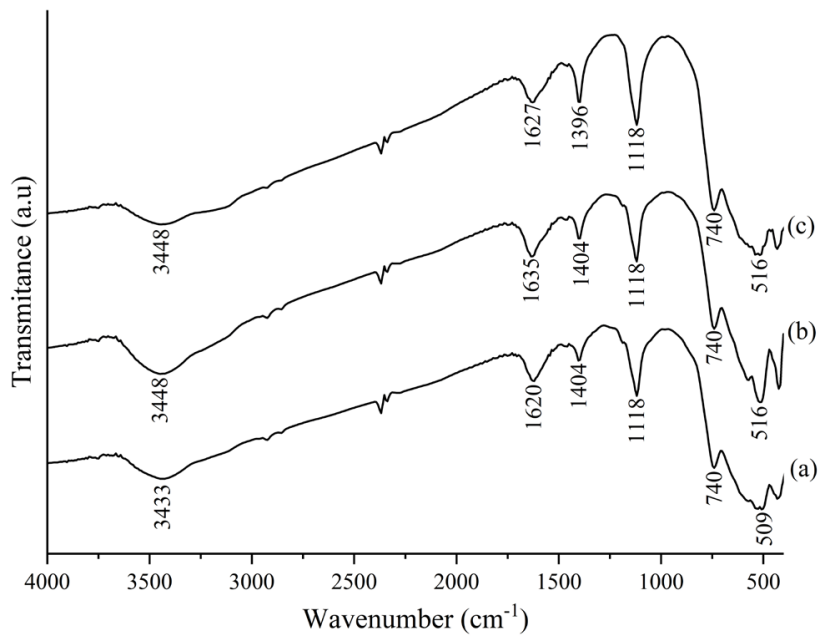

Fig. 7 Spectra FTIR of (a) Ni-SZ 1; (b) Ni-SZ 2; (c) Ni-SZ 3 after the acid test 


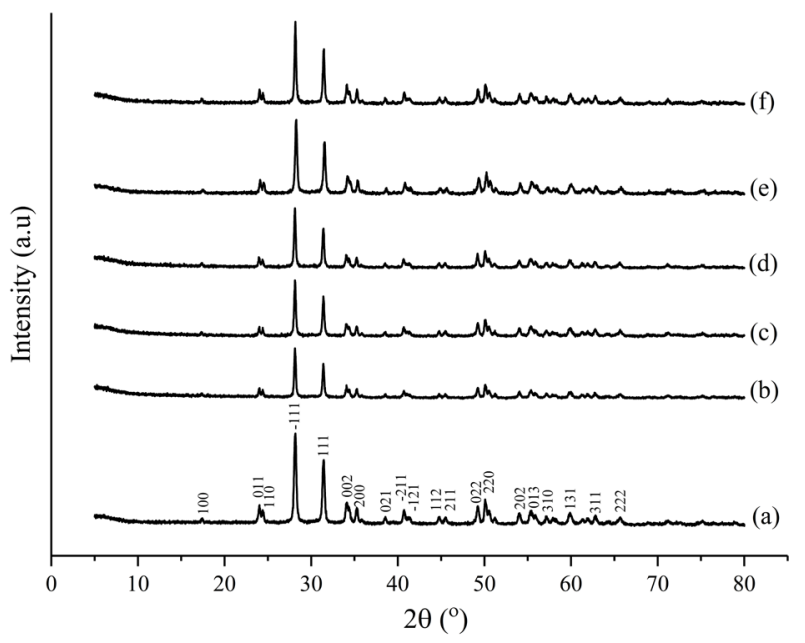

Fig. 8 Diffractogram of (a) $\mathrm{ZrO}_{2}$; (b) SZ 1.5-500; (c) SZ 1.5-550; (d) SZ 1.5-600; (e) SZ 1.5-650; (f) SZ 1.5-700

This data also shows that the higher calcination temperature can increase the intensity of these three peaks because of the decomposition of sulfate on the $\mathrm{ZrO}_{2}$ surface at high temperatures.

Diffractograms of SZ 1.5-500, Ni-SZ 1, Ni-SZ 2, Ni-SZ 3 are presented in Fig. 9. Ni-SZ diffractogram shows that $\mathrm{Ni}$ impregnation decreases the peaks intensity at $2 \theta=28.16^{\circ} ; 31.42^{\circ}$, and $50.05^{\circ}$ because of the Ni coverage on the SZ 1.5-500 surface. The peak of Ni was not detected because the amount of $\mathrm{Ni}$ on the surface of the catalyst relatively low.

The crystal size calculation of the particle is carried out by the Scherrer equation are listed in Table 2 . The result shows that sulfation followed by calcination and nickel impregnation process change the average crystal size of the $\mathrm{ZrO}_{2}$. The data indicate that higher calcination temperature

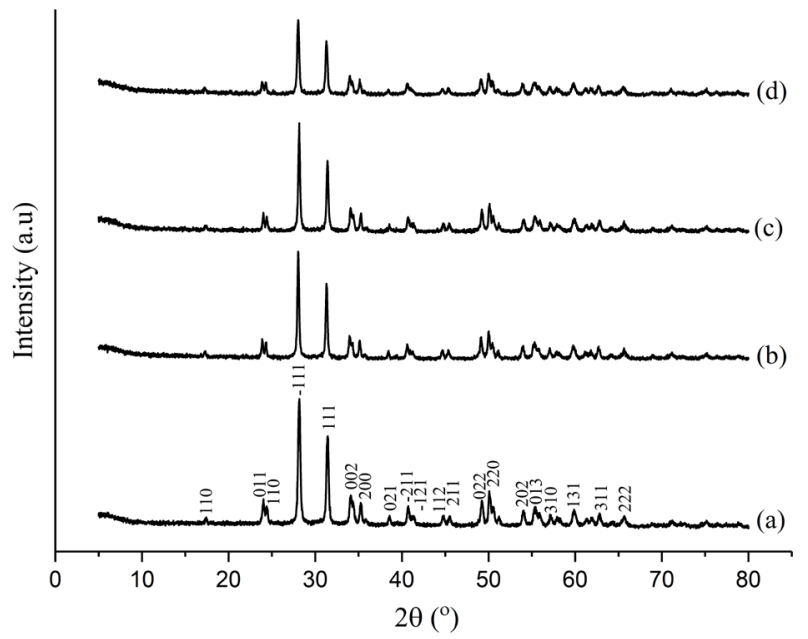

Fig. 9 Diffractogram of (a) SZ 1.5-500; (b) Ni-SZ 1; (c) Ni-SZ 2; (d) Ni-SZ 3
Table 2 Crystal size of catalysts

\begin{tabular}{lc}
\hline Catalyst & Crystal size $(\mathrm{nm})$ \\
\hline $\mathrm{ZrO}_{2}$ & 54.38 \\
$\mathrm{SZ} 1.5-500$ & 69.92 \\
$\mathrm{SZ} 1.5-550$ & 48.95 \\
$\mathrm{SZ} 1.5-600$ & 48.94 \\
$\mathrm{SZ} 1.5-650$ & 44.51 \\
$\mathrm{SZ} 1.5-700$ & 34.96 \\
$\mathrm{Ni}-\mathrm{SZ} 1$ & 69.92 \\
$\mathrm{Ni}-\mathrm{SZ} 2$ & 48.95 \\
$\mathrm{Ni}-\mathrm{SZ} \mathrm{3}$ & 48.94 \\
\hline
\end{tabular}

and Ni loading can decrease the crystal size. These phenomena are occurred due to crystal defect that caused by high sulfation, and followed by calcination and Ni loading.

\subsection{Scanning Electron Microscopy-Energy Dispersive Spectrometry (SEM-EDS) mapping}

The SEM images with magnitude 5000× present in Fig. 10 indicate that all the catalysts have a rough surface and irregular shape. The modification of $\mathrm{ZrO}_{2}$ with sulfation and Ni loading does not change the surface structure significantly. The characterization of EDS based on the overall map listed in Table 3 shows that the sulfation process increases the mass percent of $\mathrm{S}$, likewise with the impregnation of Ni, which increases Ni mass percent.

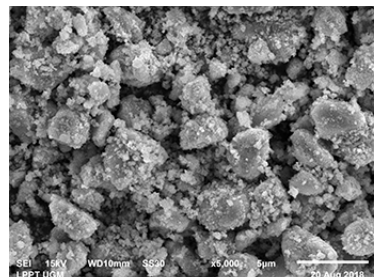

(a)

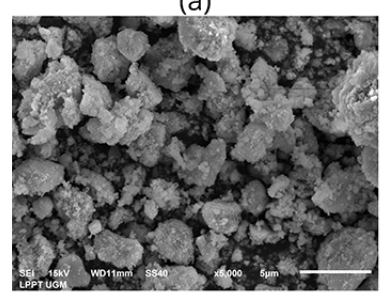

(c)

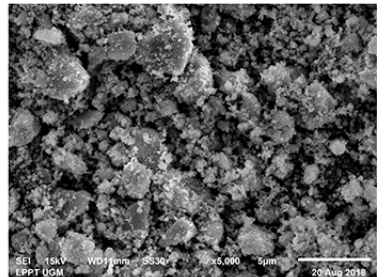

(b)

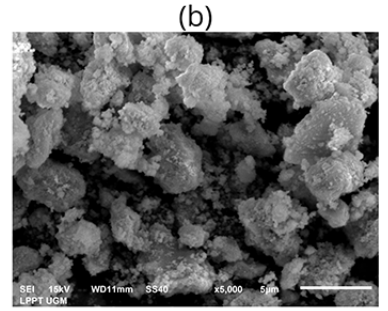

(d)

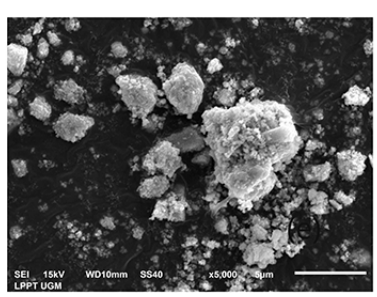

(e)
Fig. 10 Surface morphology of (a) $\mathrm{ZrO}_{2}$; (b) SZ 1.5-500; (c) Ni-SZ 1; (d) Ni-SZ 2; (e) Ni-SZ 3 
Table 3 Elements on the catalyst surface

\begin{tabular}{lcccc}
\hline \multirow{2}{*}{ Catalyst } & \multicolumn{4}{c}{ Mass (wt\%) } \\
& $\mathrm{Zr}$ & $\mathrm{O}$ & $\mathrm{S}$ & $\mathrm{Ni}$ \\
\hline $\mathrm{ZrO}_{2}$ & 78.00 & 22.00 & - & - \\
$\mathrm{SZ} \mathrm{1.5-500}$ & 75.52 & 26.66 & 0.82 & - \\
$\mathrm{Ni}-\mathrm{SZ} \mathrm{1}$ & 71.24 & 26.69 & 1.20 & 0.61 \\
$\mathrm{Ni}-\mathrm{SZ} \mathrm{2}$ & 71.07 & 26.74 & 0.66 & 1.12 \\
$\mathrm{Ni}-\mathrm{SZ} \mathrm{3}$ & 70.23 & 26.87 & 1.18 & 1.72 \\
\hline
\end{tabular}

These results indicate that sulfate and $\mathrm{Ni}$ impregnation have been successfully carried out. The amount of $\mathrm{Ni}$ detected by EDS in all Ni-SZ is lower than the amount of Ni that impregnated. This phenomenon occurred due to inadequate mixing between $\mathrm{Ni}$ precursor and $\mathrm{SZ}$ as a result of the absence of a stirring process during the impregnation process. The distribution of S on SZ 1.5-500 and $\mathrm{Ni}$ on Ni-SZ is present in the mapping images shown in Fig. 11. Based on the mapping result, it can be seen that sulfur on SZ 1.5-500 and Ni on Ni-SZ 1, Ni-SZ 2, Ni-SZ 3 are equally dispersed on the catalyst surface.

\subsection{Inductively Couple Plasma (ICP)}

The data of the Ni percentage analysis using the ICP method are listed in Table 4. Based on the ICP analysis, it can be known that the impregnation of $\mathrm{Ni}$ in the SZ 1.5-500 matrix with the hydrothermal method is successfully carried out with an average loading value of $60 \%$. This data shows that the concentration of impregnated $\mathrm{Ni}$ is smaller than the initial concentration used. These results may be due to inadequate mixing between

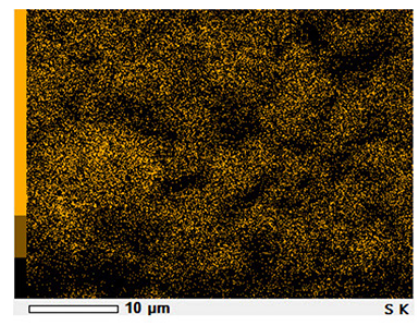

(a)

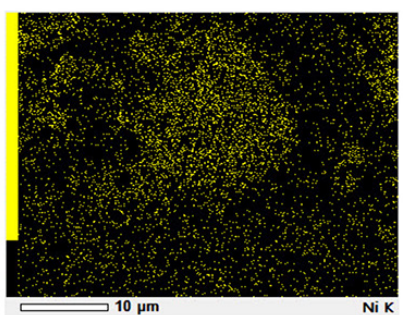

(c)

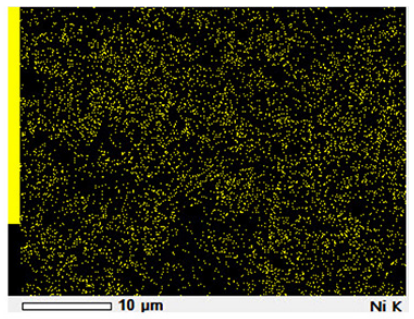

(b)

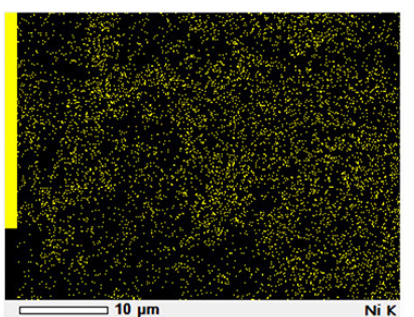

(d)
Fig. 11 The mapping of (a) S on SZ 1.5-500; (b) Ni on Ni-SZ 1; (c) Ni on Ni-SZ 2; (d) Ni on Ni-SZ 3
Table 4 Percentages of Ni in SZ

\begin{tabular}{lc}
\hline Catalyst & Ni percentage (wt $\%)$ \\
\hline Ni-SZ 1 & 0.59 \\
Ni-SZ 2 & 1.23 \\
Ni-SZ 3 & 1.80 \\
\hline
\end{tabular}

Ni precursor and SZ 1.5-500 due to the absence of the stirring step during the impregnation process. Besides that, Utami et al. [23] explain that the lower metal contents than the initial concentrations are caused by metal competition to bind in the catalyst. Some of the weakly bonded metal will be released from SZ 1.5-500 matrix [23].

\subsection{Gas Sorption Analysis (GSA)}

The specific surface area, total pore volume, and average pore diameter of catalysts are listed in Table 5. The BET isothermal nitrogen $\left(\mathrm{N}_{2}\right)$ adsorption-desorption method is applied to derive the specific surface area data, and the BJH desorption method has been used to calculate the average pore diameter. SZ 1.5-500 has a lower surface area than the $\mathrm{ZrO}_{2}$ catalyst because of the sulfate agglomeration in the pore of the catalysts [23]. On the other hand, the impregnation of $\mathrm{Ni}$ increases the specific surface area of the catalysts as a consequence of $\mathrm{Ni}$ dispersion in the pore and SZ surface. The average pore diameter of Ni-SZ drops significantly as a result of pore-blocking by $\mathrm{Ni}$ impregnation. The isotherm curves of $\mathrm{N}_{2}$ adsorption-desorption are presented in Fig. 12.

The isotherm curves of all catalysts follow the isotherm curve type 4 . This type of isotherm presents a hysteresis loop related to capillary condensation in mesopores and has a limiting uptake over a range of high $p / p_{0}$. In addition, this isotherm curve has four types of hysteresis loops showing the characteristics of pore material [33]. The shape of $\mathrm{ZrO}_{2}$ and SZ 1.5-500 isotherm curves show hysteresis type 3 that does not exhibit adsorption limits at high $p / p_{0}$, and there is an aggregate of plate-like particles forming slit-shaped pores. For Ni-SZ 1, 2 and 3 catalysts are classified to hysteresis type 4 suggests the presence of narrow pore in the material. The difference in pore

Table 5 Textural properties of catalyst

\begin{tabular}{lccc}
\hline Catalyst & $\begin{array}{c}\text { Specific surface } \\
\text { area }\left(\mathrm{m}^{2} \mathrm{~g}^{-1}\right)\end{array}$ & $\begin{array}{c}\text { Total pore } \\
\text { volume }\left(\mathrm{cc} \mathrm{g}^{-1}\right)\end{array}$ & $\begin{array}{c}\text { Average pore } \\
\text { diameter }(\mathrm{nm})\end{array}$ \\
\hline $\mathrm{ZrO}_{2}$ & 5.63 & 0.04 & 30.72 \\
$\mathrm{SZ} \mathrm{1.5-500}$ & 4.04 & 0.04 & 35.84 \\
$\mathrm{Ni}-\mathrm{SZ} \mathrm{1}$ & 7.09 & 0.06 & 3.82 \\
$\mathrm{Ni}-\mathrm{SZ} \mathrm{2}$ & 8.75 & 0.05 & 3.82 \\
$\mathrm{Ni}-\mathrm{SZ} \mathrm{3}$ & 11.68 & 0.05 & 3.82 \\
\hline
\end{tabular}




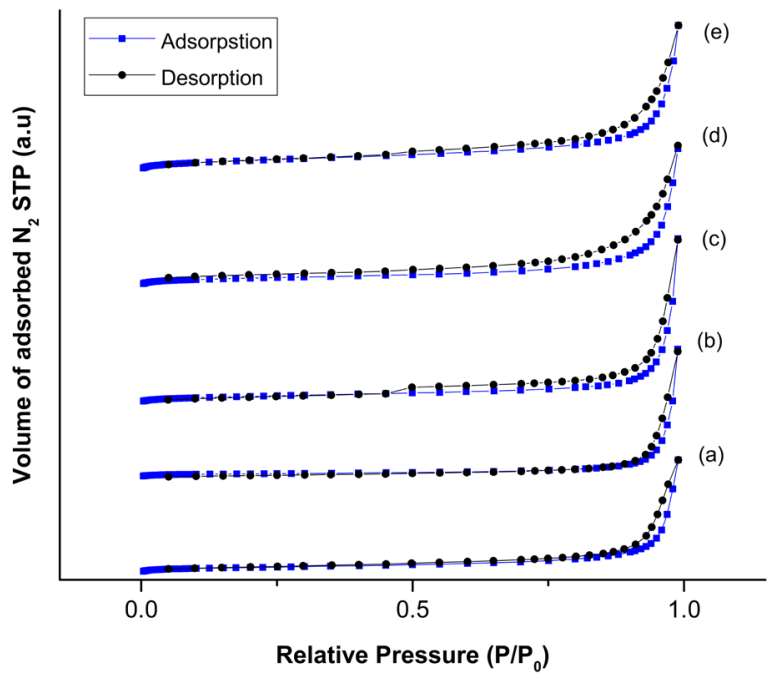

Fig. 12 Isotherm curves of (a) $\mathrm{ZrO}_{2}$; (b) SZ 1.5-500; (c) Ni-SZ 1; (d) Ni-SZ 2; (e) Ni-SZ 3

shape between Ni-SZ 1, 2, 3, and $\mathrm{ZrO}_{2}$, SZ 1.5-500 may be caused by the dispersion of $\mathrm{Ni}$ narrowing of the pore. The pore size distribution curve based on BJH desorption method presented in Fig. 13 shows the catalysts pore predominantly of mesopores $(2-50 \mathrm{~nm})$.

\subsection{Analysis of hydrocracking products}

Used palm cooking oil as feed has been transesterified with methanol to form fatty acid methyl ester before analyzed with GC-MS. The spectrum data is shown in Fig. 14.

The data from GC-MS analysis and the distribution of fatty acid of the triglyceride are presented in Table 6 . These analyses indicate that used palm cooking oil contained $\mathrm{C}_{17}$ and $\mathrm{C}_{19}$ compounds. The distribution of fatty acid of the triglyceride was calculated with Eq. (7).

Distribution $=\frac{\text { Area of coumpound } X}{\text { Total area }} \times 100 \%$

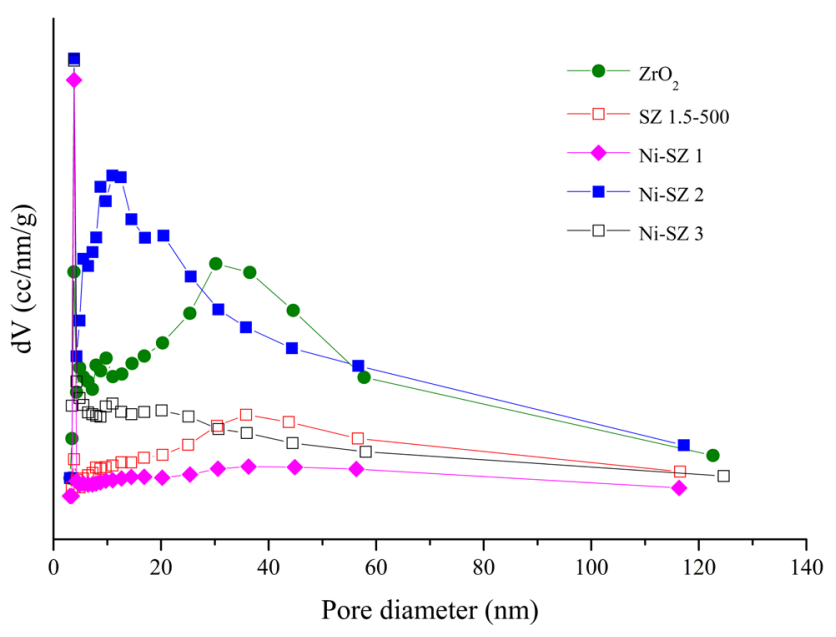

Fig. 13 Pore size distribution curves of catalysts
The optimum hydrocracking temperature was determined based on the thermal cracking temperature, producing the largest conversion into liquid products. The thermal cracking analysis (Fig. 15) indicates that the highest conversion to liquid fuel is achieved at $350{ }^{\circ} \mathrm{C}$. The temperature at $325^{\circ} \mathrm{C}$ gives the smallest amount of liquid fuel because of non-optimum feed evaporation, and this is proved by the large residue that exists. Temperature $375^{\circ} \mathrm{C}$ produces a lower liquid yield than $350^{\circ} \mathrm{C}$. However, the increasing temperature until $375^{\circ} \mathrm{C}$ decreases the liquid product because the evaporation of feed is too fast, so it could not be adequately condensed. The other reason is that coke formation increases, and it covers the active sites, consequently inhibit the mass transfer of the feed to the active site of the catalyst, and it lowered activity to form the liquid product [34]. The hydrocracking reaction is applied with $\mathrm{ZrO}_{2}, \mathrm{SZ} 1.5-500, \mathrm{Ni}-\mathrm{SZ} 1, \mathrm{Ni}-\mathrm{SZ} 2$, and Ni-SZ 3 catalyst. The result of their catalytic activity test is depicted in Fig. 16. Based on this activity test, SZ 1.5-500 produces the lowest liquid product conversion compared to the other catalysts. This is due to its lowest surface area and its properties that are easily deactivated by coke. Coke formation on the SZ 1.5-500 blocks the active site and decreases its activity to produce a liquid product [35]. The hydrocracking using Ni-SZ catalyst with a higher concentration of $\mathrm{Ni}$ produces a higher liquid product due to the high specific surface area and the acidity of Ni-SZ. The acidity of the catalyst directly proportional to its catalytic activity for the hydrocracking reaction [36].

In general, liquid products from the hydrocracking of used cooking oil consist of hydrocarbons and non-hydrocarbons. The non-hydrocarbon products are the uncracked feed, while the hydrocarbon products are derived from the cracked fatty acids.

The selectivity of catalyst to light $\left(\mathrm{C}_{1}-\mathrm{C}_{4}\right)$, gasoline $\left(\mathrm{C}_{5}-\mathrm{C}_{12}\right)$, diesel $\left(\mathrm{C}_{13}-\mathrm{C}_{20}\right)$, and non-hydrocarbon fraction showed in Table 7. This analysis (Table 7) shows that the liquid products of all catalysts predominantly by gasoline fractions and the highest gasoline produced by Ni-SZ 3. This phenomenon is due to Ni-SZ 3 having the highest acidity, surface area, and stability of the catalysts.

Several treatments have been carried out to produce gasoline from used cooking oil as listed in Table 8 .

Based on Table 8, we can see that the activity of the Ni-SZ 3 inferior against Ni-Mo Alumina [37] but it more superior against ZSM-5 [38] and Mo-SBA-15 [39] although a lower temperature operation was carried out. This is indicated that Ni-SZ 3 is better catalyst to convert used cooking oil to gasoline than Mo-SBA-15 and ZSM-5 while worse than Ni-Mo Alumina. 


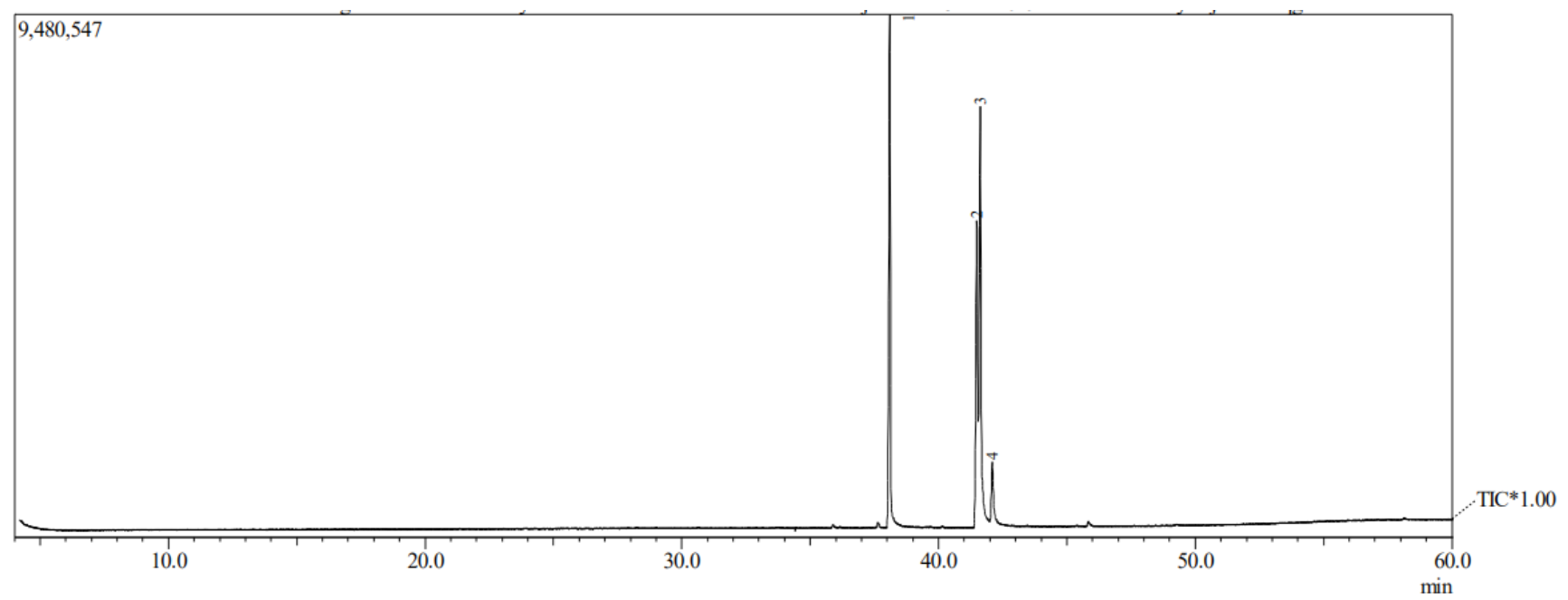

Fig. 14 GC spectrum of used cooking oil feed

\begin{tabular}{lcccc}
\multicolumn{5}{c}{ Table 6 GC-MS results of used cooking oil } \\
\hline Peak & $\begin{array}{c}\text { Retention } \\
\text { time (min) }\end{array}$ & $\begin{array}{c}\text { Area } \\
(\%)\end{array}$ & Compound & $\begin{array}{c}\text { Distribution } \\
(\%)\end{array}$ \\
\hline 1 & 38.100 & 34.79 & Methyl Hexadecanoate & 34.79 \\
2 & 41.492 & 25.34 & $\begin{array}{c}\text { Methyl } \\
\text { 9,12-Hexadecedienoate }\end{array}$ & 25.33 \\
3 & 41.624 & 34.60 & $\begin{array}{c}\text { Methyl } \\
\text { 10-Octadecenoate }\end{array}$ & 34.60 \\
4 & 42.093 & 5.28 & Methyl Octadecenoate & 5.28 \\
\hline
\end{tabular}

Five main compounds from the liquid products are listed in Table 9, and most of them are aromatic hydrocarbons. The formation of aromatic hydrocarbon from triglyceride occurred through nine interconnected reactions of triglyceride molecules and intermediates:
1. hydrogenolysis, forming fatty acids and propane;

2. dehydrogenation of diene chains producing triene fatty acids;

3. conjugation of double bonds system in triene chain;

4. migration of double bonds (conjugated system) along the chain of fatty acid towards the terminus of hydrocarbon chain (carboxylic or methyl group);

5. deoxygenation of carboxylic groups in fatty acids;

6. intermolecular Diels-Alder reaction of conjugated triene system forming a cyclohexene ring inside or at the end of hydrocarbon chain;

7. dehydrogenation of cyclohexene to aromatic ring;

8. hydrocracking of alkyl chains;

9. isomerization of alkyl chains [40].

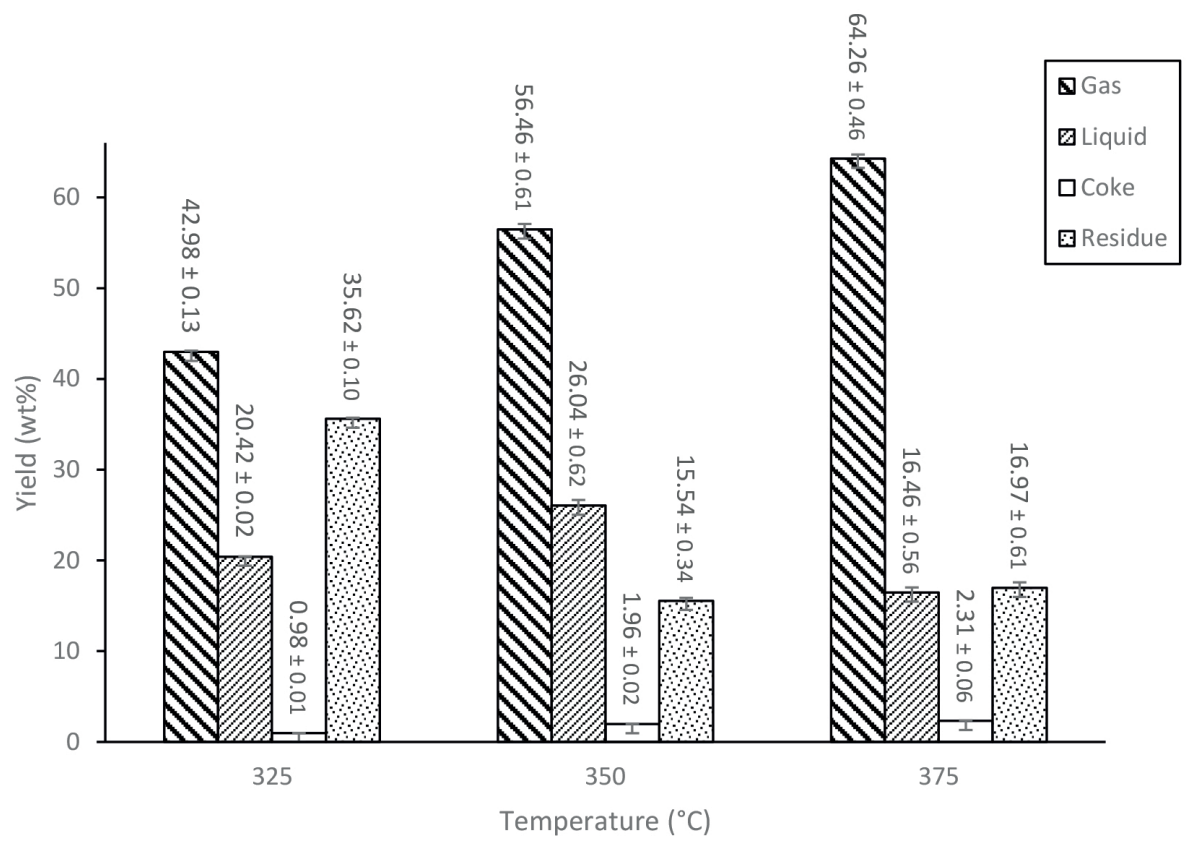

Fig. 15 The results of the thermal cracking 


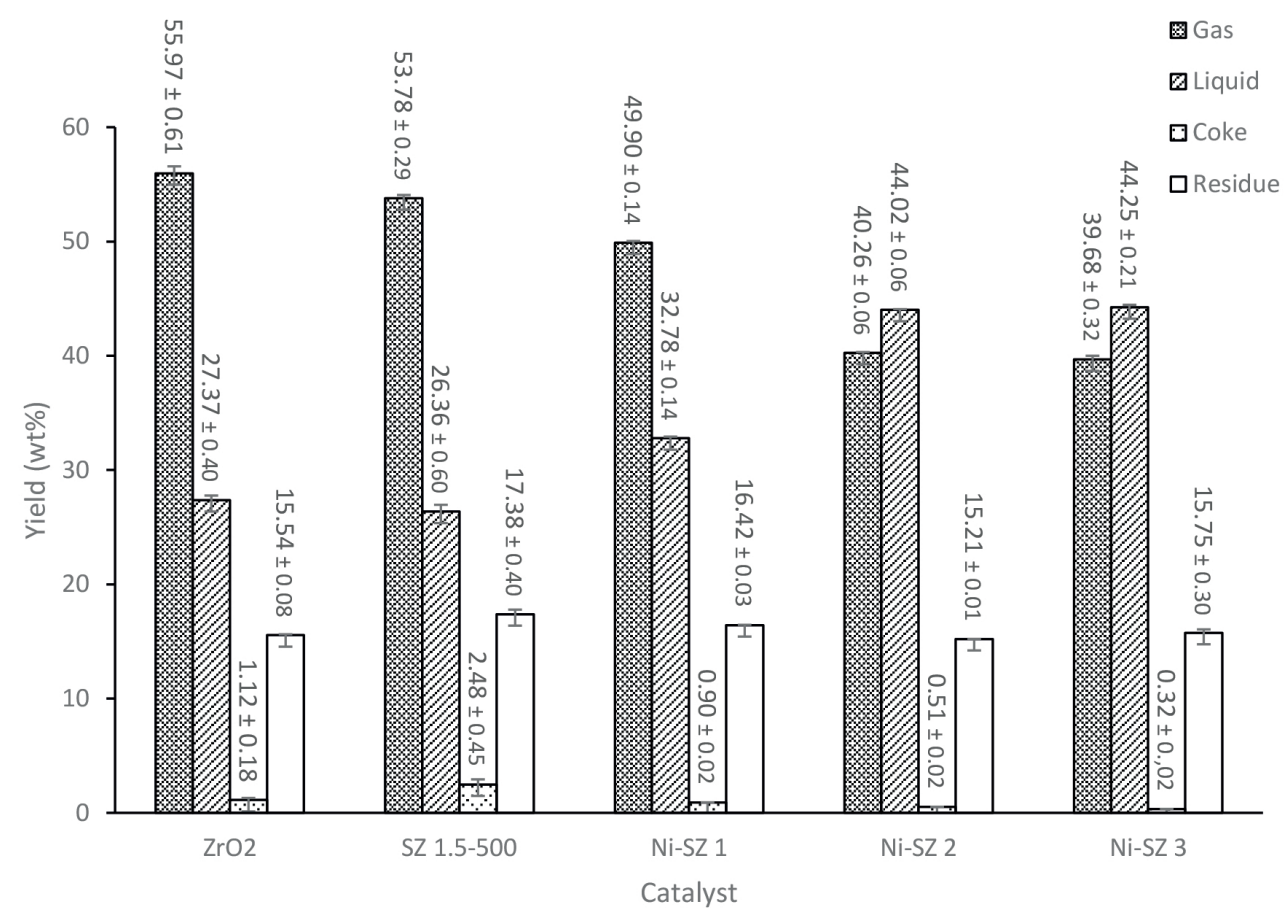

Fig. 16 Results of hydrocracking

Table 7 Result of catalyst selectivity test

\begin{tabular}{|c|c|c|c|c|}
\hline \multirow{2}{*}{ Catalyst } & \multicolumn{4}{|c|}{ Selectivity (wt\%) } \\
\hline & $\left(\mathrm{C}_{1}-\mathrm{C}_{4}\right)$ & $\left(\mathrm{C}_{5}-\mathrm{C}_{12}\right)$ & $\left(\mathrm{C}_{13}-\mathrm{C}_{20}\right)$ & Non- hydrocarbon \\
\hline $\mathrm{ZrO}_{2}$ & 1.86 & 77.31 & 19.26 & 1.57 \\
\hline SZ 1.5-500 & 1.93 & 67.38 & 28.15 & 2.54 \\
\hline Ni-SZ 1 & 0.00 & 51.59 & 15.16 & 33.25 \\
\hline Ni-SZ 2 & 0.00 & 87.01 & 12.99 & 0.00 \\
\hline Ni-SZ 3 & 0.00 & 100.00 & 0.00 & 0.00 \\
\hline \multicolumn{5}{|c|}{$\begin{array}{l}\text { Table } 8 \text { Summary about hydrocracking of used cooking oil research } \\
\text { with different catalyst }\end{array}$} \\
\hline \multicolumn{2}{|l|}{ Catalyst } & $\begin{array}{l}\text { Catalyst:Oil } \\
\text { Ratio }\end{array}$ & $\begin{array}{c}\text { Operation } \\
\text { Temperature } \\
\left({ }^{\circ} \mathrm{C}\right)\end{array}$ & $\begin{array}{c}\text { Gasoline } \\
\text { product } \\
(\mathrm{wt} \%)\end{array}$ \\
\hline \multicolumn{2}{|l|}{$\begin{array}{l}\text { Ni-Mo } \\
\text { Alumina [37] }\end{array}$} & $1: 75$ & 250 & 59.50 \\
\hline \multicolumn{2}{|l|}{ ZSM-5 [38] } & $1: 8$ & 400 & 13.41 \\
\hline \multicolumn{2}{|c|}{ Mo-SBA-15 [39] } & $1: 100$ & 500 & 42.46 \\
\hline \multicolumn{2}{|l|}{ This work } & $1: 100$ & 350 & 44.25 \\
\hline
\end{tabular}

Aromatic hydrocarbons are not expected to appear in fuels because of their high combustion energy and toxicity. Further research is needed to increase the conversion value of liquid products and reduce the content of aromatic compounds in the gasoline fraction of hydrocracking products so that potentially be used in the future as a safe, economical, and environmentally friendly fuel source. One of the problems the cause of a large amount of aromatics product is the low hydrogenation activity of
Table 9 Prediction of compounds in liquid product

\begin{tabular}{|c|c|c|c|c|}
\hline Catalyst & Peak & $\begin{array}{l}\text { Retention time } \\
(\mathrm{min})\end{array}$ & $\begin{array}{c}\text { Area } \\
(\%)\end{array}$ & Compound \\
\hline \multirow{5}{*}{$\mathrm{ZrO}_{2}$} & 5 & 2.968 & 6.82 & Benzene \\
\hline & 10 & 4.541 & 10.38 & Toluene \\
\hline & 12 & 5.311 & 4.27 & Octane \\
\hline & 16 & 8.731 & 4.84 & Nonane \\
\hline & 51 & 28.102 & 9.93 & Hexadecane \\
\hline \multirow{5}{*}{ SZ $1.5-500$} & 6 & 2.975 & 6.13 & Benzene \\
\hline & 10 & 4.553 & 7.27 & Toluene \\
\hline & 12 & 5.327 & 3.64 & Octane \\
\hline & 16 & 8.745 & 4.91 & Nonane \\
\hline & 41 & 28.123 & 15.61 & Hexadecane \\
\hline \multirow{5}{*}{ Ni-SZ 1} & 5 & 4.507 & 5.25 & Toluene \\
\hline & 6 & 5.023 & 3.35 & 1-octene \\
\hline & 7 & 5.262 & 3.49 & Octane \\
\hline & 10 & 8.351 & 3.06 & 1-nonene \\
\hline & 29 & 32.548 & 2.83 & 8-heptadecene \\
\hline \multirow{5}{*}{ Ni-SZ 2} & 4 & 4.514 & 17.19 & Toluene \\
\hline & 6 & 5.271 & 6.41 & Octane \\
\hline & 9 & 8.359 & 5.52 & 1-nonene \\
\hline & 11 & 8.680 & 8.10 & Nonane \\
\hline & 26 & 28.078 & 7.60 & Tetradecane \\
\hline \multirow{5}{*}{ Ni-SZ 3} & 2 & 2.947 & 6.29 & Benzene \\
\hline & 5 & 4.508 & 14.18 & Toluene \\
\hline & 7 & 5.263 & 4.43 & Octane \\
\hline & 10 & 8.351 & 4.38 & 1-nonene \\
\hline & 12 & 8.668 & 6.08 & Nonane \\
\hline
\end{tabular}


the catalyst [41-43]. To solve this problem, we suggested increasing the hydrogenation activity of the catalyst by insert two kinds of metals that have high hydrogenation activity to SZ to form a bimetallic catalyst.

\section{Conclusions}

Synthesis and application of Ni-SZ for the hydrocracking process were successfully performed. The data showed that sulfation on $\mathrm{ZrO}_{2}$ increases the total acidity, but on the other hand, this reduces crystallinity, average crystal size, and specific surface area. The increase of calcination temperature can decrease the acidity value, crystallinity, and average crystal size. The impregnation of $\mathrm{Ni}$ can increase the acidity value and specific surface area of the catalyst. Furthermore, in the hydrocracking process, this impregnation is able to increase the activity and selectivity in

\section{References}

[1] Li, T., Cheng, J., Huang, R., Zhou, J., Cen, K. "Conversion of waste cooking oil to jet biofuel with nickel-based mesoporous zeolite Y catalyst", Bioresource Technology, 197, pp. 289-294, 2015. https://doi.org/10.1016/j.biortech.2015.08.115

[2] Nanda, S., Rana, R., Hunter, H. N., Fang, Z., Dalai, A. K., Kozinski, J. A. "Hydrothermal catalytic processing of waste cooking oil for hydrogen-rich syngas production", Chemical Engineering Science, 195, pp. 935-945, 2019. https://doi.org/10.1016/j.ces.2018.10.039

[3] Meller, E., Gutkin, V., Aizenshtat, Z., Sasson, Y. "Catalytic Hydrocracking -Hydrogenation of Castor Oil Fatty Acid Methyl Esters over Nickel Substituted Polyoxometalate Catalyst", Chemistry Select, 1(20), pp. 6396-6405, 2016. https://doi.org/10.1002/slct.201601030

[4] Maclaren, D. D., Cunningham, A. R., Hendricks, G. W., Kelley, A. E. "Hydrocracking, an example of modern hydrogen processing", The Canadian Journal of Chemical Engineering, 42(2), pp. 88-94, 1964. https://doi.org/10.1002/cjce.5450420212

[5] Twaiq, F. A., Zabidi, N. A. M., Bhatia, S. "Catalytic Conversion of Palm Oil to Hydrocarbons: Performance of Various Zeolite Catalysts", Industrial and Engineering Chemistry Research, 38(9), pp. 3230-3237, 1999.

https://doi.org/10.1021/ie980758f

[6] Sang, O. Y. "Biofuel Production from Catalytic Cracking of Palm Oil", Energy Sources, 25(9), pp. 859-869, 2003.

https://doi.org/10.1080/00908310390221309

[7] Akmaz, S., Caglayan, P. A. "Effect of Catalyst, Temperature, and Hydrogen Pressure on Slurry Hydrocracking Reactions of Naphthalene", Chemical Engineering and Technology, 38(5), pp. 917-930, 2015. https://doi.org/10.1002/ceat.201400300

[8] Khan, I., Saeed, K., Khan, I. "Nanoparticles: Properties, applications and toxicities", Arabian Journal of Chemistry, 12(7), pp. 908-931, 2019.

https://doi.org/10.1016/j.arabjc.2017.05.011 gasoline fractions as well. The sulfated zirconia catalyst loaded with 3 wt $\%$ of (Ni-SZ 3) has proven successfully producing the highest liquid yield $(44.25 \mathrm{wt} \%)$ and selectivity in gasoline fractions (100\%) compared to the other catalysts. Although the selectivity in the gasoline fraction is $100 \%$, the compounds in it are dominated by unwanted aromatic compounds, so it is necessary to improve the catalyst to solve this problem.

\section{Acknowledgments}

This research was supported by the Indonesia Ministry of Research, Technology, and Higher Education (KEMENRISTEKDIKTI) under the World Class Research (WCR) 2019 Program with contract number: 1980/UN1. DITLIT/DIT-LIT/LT/2019. In this research, all authors have contributed equally.

[9] Yuan, H., Dong, Z., He, J., Wang, Y., Zhang, H. "Surface characterization of sulfated zirconia and its catalytic activity for epoxidation reaction of castor oil", Chemical Engineering Communications, 206(12), pp. 1618-1627, 2019 https://doi.org/10.1080/00986445.2018.1560274

[10] Keiteb, A. S., Saion, E., Zakaria, A., Soltani, N. "Structural and Optical Properties of Zirconia Nanoparticles by Thermal Treatment Synthesis", Journal of Nanomaterials, 2016, Article number: 1913609, 2016. https://doi.org/10.1155/2016/1913609

[11] Osatiashtiani, A., Lee, A. F., Brown, D. R., Melero, J. A., Morales, G., Wilson, K. "Bifunctional $\mathrm{SO}_{4} / \mathrm{ZrO}_{2}$ catalysts for 5-hydroxymethylfufural (5-HMF) production from glucose", Catalysis Science and Technology, 4(2), pp. 333-342, 2014. https://doi.org/10.1039/c3cy00409k

[12] Saravanan, K., Tyagi, B., Shukla, R. S., Bajaj, H. C. "Solvent free synthesis of methyl palmitate over sulfated zirconia solid acid catalyst", Fuel, 165, pp. 298-305, 2016. https://doi.org/10.1016/j.fuel.2015.10.043

[13] Fernández-Morales, J. M., Castillejos, E., Asedegbega-Nieto, E., Dongil, A. B., Rodríguez-Ramos, I., Guerrero-Ruiz, A. "Comparative Study of Different Acidic Surface Structures in Solid Catalysts Applied for the Isobutene Dimerization Reaction", Nanomaterials, 10(6), Article number: 1235, 2020. https://doi.org/10.3390/nano10061235

[14] Said, A. E.-A. A., El-Aal, M. A. "Effect of different metal sulfate precursors on structural and catalytic performance of zirconia in dehydration of methanol to dimethyl ether", Journal of Fuel Chemistry and Technology, 46(1), pp. 67-74, 2018. https://doi.org/10.1016/s1872-5813(18)30004-5

[15] Li, W., Ni, Y., Liu, W., Xing, W., Xu, N. "Preparation and properties of sulfated zirconia for hydrolysis of ethyl lactate", Korean Journal of Chemical Engineering, 30(6), pp. 1222-1228, 2013. https://doi.org/10.1007/s11814-013-0036-5 
[16] Wang, S., Pu, J., Wu, J., Liu, H., Xu, H., Li, X., Wang, H. " $\mathrm{SO}_{4}^{2-} / \mathrm{ZrO}_{2}$ as a Solid Acid for the Esterification of Palmitic Acid with Methanol: Effects of the Calcination Time and Recycle Method", ACS Omega, 5(46), pp. 30139-30147, 2020. https://doi.org/10.1021/acsomega.0c04586

[17] Utami, M., Trisunaryanti, W., Shida, K., Tsushida, M., Kawakita, H., Ohto, K., Wijaya, K., Tominaga, M. "Hydrothermal preparation of a platinum-loaded sulphated nanozirconia catalyst for the effective conversion of waste low density polyethylene into gasoline-range hydrocarbons", RSC Advances, 9(71), pp. 41392-41401, 2019. https://doi.org/10.1039/c9ra08834b

[18] Hasanova, A., Alizade, A., Ahmadova, R., Mukhtarova, G., Abbasov, V. "Hydrocracking process of fuel oil using halloysite modified by different methods", Applied Petrochemical Research, 9(3-4), pp. 199-209, 2019. https://doi.org/10.1007/s13203-019-00234-7

[19] Jiang, Y., Li, X., Qin, Z., Ji, H. "Preparation of Ni/bentonite catalyst and its applications in the catalytic hydrogenation of nitrobenzene to aniline", Chinese Journal of Chemical Engineering, 24(9), pp. 1195-1200, 2016. http://doi.org/10.1016/j.cjche.2016.04.030

[20] Permata, M. L., Trisunaryanti, W., Falah, I. I., Hapsari, M. T., Fatmawati, D. A. "The Effect of Nickel Content Impregnated on Zeolite toward Catalytic Activity and Selectivity for Hydrotreating of Cashew Nut Shell Liquid Oil", Rasayan Journal of Chemistry, 13(1), pp. 772-779, 2020 https://doi.org/10.31788/RJC.2020.1315529

[21] Faro, A. C., dos Santos, A. C. B. "Cumene hydrocracking and thiophene HDS on niobia-supported Ni, Mo and Ni-Mo catalysts", Catalysis Today, 118(3-4), pp. 402-409, 2006. https://doi.org/10.1016/j.cattod.2006.07.027

[22] Zhao, X., Wei, L., Cheng, S., Julson, J. "Review of Heterogeneous Catalysts for atalytically Upgrading Vegetable Oils into Hydrocarbon Biofuels", Catalysts, 7(3), Article number: 83, 2017. https://doi.org/10.3390/catal7030083

[23] Utami, M., Wijaya, K., Trisunaryanti, W. "Pt-promoted sulfated zirconia as catalyst for hydrocracking of LDPE plastic waste into liquid fuels", Materials Chemistry and Physics, 213, pp. 548-555, 2018. https://doi.org/10.1016/j.matchemphys.2018.03.055

[24] Heshmatpour, F., Aghakhanpour, R. B. "Synthesis and characterization of superfine pure tetragonal nanocrystalline sulfated zirconia powder by a non-alkoxide sol-gel route", Advanced Powder Technology, 23(1), pp. 80-87, 2012. https://doi.org/10.1016/j.apt.2010.12.012

[25] Luo, Y., Mei, Z., Liu, N., Wang, H., Han, C., He, S. "Synthesis of mesoporous sulfated zirconia nanoparticles with high surface area and their applies for biodiesel production as effective catalysts", Catalysis Today, 298, pp. 99-108, 2017. https://doi.org/10.1016/j.cattod.2017.05.047

[26] Ore, M. S. L., Wijaya, K., Trisunaryanti, W., Saputri, W. D., Heraldy, E., Yuwana, N. W., Hariani, P. L., Budiman, A., Sudiono, $\mathrm{S}$. "The synthesis of $\mathrm{SO}_{4} / \mathrm{ZrO}_{2}$ and $\mathrm{Zr} / \mathrm{CaO}$ catalysts via hydrothermal treatment and their application for conversion of low-grade coconut oil into biodiesel", Journal of Environmental Chemical Engineering, 8(5), Article number: 104205, 2020. https://doi.org/10.1016/j.jece.2020.104205
[27] Tyagi, B., Mishra, M. K., Jasra, R. V. "Solvent free synthesis of 7-isopropyl-1,1-dimethyltetralin by the rearrangement of longifolene using nano-crystalline sulfated zirconia catalyst", Journal of Molecular Catalyst A: Chemical, 301(1-2), pp. 67-78, 2009. https://doi.org/10.1016/j.molcata.2008.11.011

[28] Li, S., Song, H., Hu, Y., Li, F., Chen, Y. "A novel method for the synthesis of highly stable nickel-modified sulfated zirconia catalysts for $n$-pentane isomerization", Catalysis Communications, 104, pp. 57-61, 2018. https://doi.org/10.1016/j.catcom.2017.10.019

[29] Marakatti, V. S., Marappa, S., Gaigneaux, E. M. "Sulfated zirconia: An efficient catalyst for the Friedel-Crafts monoalkylation of resorcinol with methyl tertiary butyl ether to 4-tertiary butylresorcinol", New Journal of Chemistry, 43(20), pp. 7733-7742, 2019. https://doi.org/10.1039/c9nj01311c

[30] Popova, M., Szegedi, Á., Lazarova, H., Dimitov, M., Kalvachev, Y., Atanasova, G., Rictić, A., Wilde, N., Gläser, R. "Influence of the preparation method of sulfated zirconia nanoparticles for levulinic acid esterification", Reaction Kinetics, Mechanisms and Catalysis, 120(1), pp. 55-67, 2017. https://doi.org/10.1007/s11144-016-1088-4

[31] Yan, P., Li, M. M.-J., Kennedy, E., Adesina, A., Zhao, G., Setriawan, A., Strockenhuber, M. "The role of acid and metal sites in hydrodeoxygenation of guaiacol over $\mathrm{Ni} /$ Beta catalyst", Catalysis Science and Technology, 10(3), pp. 810-825, 2020. https://doi.org/10.1039/C9CY01970G

[32] Spielbauer, D., Mekhemer, G. A. H., Zaki, M. I., Knözinger, H. "Acidity of sulfated zirconia as studied by FTIR spectroscopy of adsorbed $\mathrm{CO}$ and $\mathrm{NH}_{3}$ as probe molecules", Catalysis Letters, 40(1-2), pp. 71-79, 1996. https://doi.org/10.1007/BF00807460

[33] Sing, K. S. W. "Reporting Physisorption Data for Gas/Solid Systems with Special Reference to the Determination of Surface Area and Porosity", Pure and Applied Chemistry, 54(11), pp. 2201-2218, 1982. https://doi.org/10.1351/pac198254112201

[34] Hauli, L., Wijaya, K., Syoufian, A. "Fuel Production from LDPEbased Plastic Waste over Chromium Supported on Sulfated Zirconia", Indonesian Journal of Chemistry, 20(2), pp. 422-429, 2020. https://doi.org/10.22146/ijc.45694

[35] Aboul-Gheit., A. K., Gad, F. K., Abdel-Aleem, G. M., El-Desouki, D. S., Abdel-Hamid, S. M., Ghoneim, S. A., Ibrahim, A. H. "Pt, Re and Pt-Re incorporation in sulfated zirconia as catalysts for n-pentane isomerization", Egyptian Journal of Petroleum, 23(3), pp. 303-314, 2014. https://doi.org/10.1016/j.ejpe.2014.08.006

[36] Sriningsih, W., Saerodji, M. G., Trisunaryanti, W., Triyono, Armunanto, R., Falah, I. I. "Fuel Production from LDPE Plastic Waste over Natural Zeolite Supported Ni, Ni-Mo, Co and Co-Mo Metals", Procedia Environmental Sciences, 20, pp. 215-224, 2014. https://doi.org/10.1016/j.proenv.2014.03.028

[37] Mampuru, M. B., Nkazi, D. B., Mukaya, H. E. "Hydrocracking of waste cooking oil into biogasoline in the presence of a bi-functional Ni-Mo/alumina catalyst", Energy Sources, Part A: Recovery, Utilization, and Environmental Effects, 42(20), pp. $2564-2575,2020$. https://doi.org/10.1080/15567036.2019.1610527 
[38] Onlamnao, K., Tippayawong, N. "Organic Liquid Products from Cracking of Used Cooking Oils with Commercial Catalysts", Chemical Engineering Transactions, 78, pp. 55-60, 2020. https://doi.org/10.3303/CET2078010

[39] Alisha, G. D., Trisunaryanti, W., Syoufian, A. "Hydrocracking of Waste Palm Cooking Oil into Hydrocarbon Compounds over Mo Catalyst Impregnated on SBA-15", Silicon, 49, pp. 1-7, 2021. https://doi.org/10.1007/s12633-021-01035-1

[40] Rabaev, M., Landau, M. V., Vidruk-Nehemya, R., Koukouliev, V., Zarchin, R., Herskowitz, M. "Conversion of vegetable oils on $\mathrm{Pt} / \mathrm{Al}_{2} \mathrm{O}_{3} / \mathrm{SAPO}-11$ to diesel and jet fuels containing aromatics", Fuel, 161, pp. 287-294, 2015. https://doi.org/10.1016/j.fuel.2015.08.063

[41] Massenova, A., Kalykberdiyev, M., Sass, A., Kenzin, N., Ussenov, A., Baiken, A., Rakhmetova, K. "Catalytic Technologies for Solving Environmental Problems in the Production of Fuels and Motor Transport in Kazakhstan", Catalysts, 10(10), Article number: 1197, 2020.

https://oi.org/10.3390/catal10101197
[42] Garba, M. D., Galadima, A. "Catalytic Hydrogenation of Hydrocarbons for Gasoline Production", Journal of Physical Science, 29(2), pp. 153-176, 2018. https://doi.org/10.21315/jps2018.29.2.10

[43] Wang, T., Mpourmpakis, G., Lonergan, W. W., Vlachos, D. G., Chen, J. G. "Effect of oxide supports in stabilizing desirable Pt-Ni bimetallic structures for hydrogenation and reforming reactions", Physical Chemistry Chemical Physics, 15(29), pp. 12156-12164, 2013.

https://doi.org/10.1039/c3cp44688c 